\title{
W POSZUKIWANIU SOJUSZNIKÓW? ROLA CHANATU KRYMSKIEGO I PERSJI W POLITYCE JANA III SOBIESKIEGO WOBEC IMPERIUM OSMAŃSKIEGO $(1674-1696)^{1}$
}

Natalia Królikowska-Jedlińska

http://orcid.org/0000-0002-0363-0273

Uniwersytet Warszawski

\begin{abstract}
SEARCHING FOR ALLIES? THE ROLE OF THE CRIMEAN KHANATE AND PERSIA IN THE POLICY OF JOHN III SOBIESKI TOWARDS THE OTTOMAN EMPIRE (1674-1696)
\end{abstract}

This paper discusses the role of the Crimean Khanate and the Safavid Persia in Polish-Ottoman relations during the reign of King John III Sobieski (1674-1696). It is striking that the Polish ruler repeatedly invited the Crimean khan and the Persian shah to join the anti-Ottoman coalition. Notwithstanding numerous letters and envoys dispatched by Sobieski, the Crimean Khanate remained a loyal ally to the Sublime Porte, while Persia denied to take part in the conflict. Sobieski's political plans in reference to Persia, which resulted in numerous embassies sent to the shah, increased opportunities of Polish missionaries to minister in this country. An especially interesting project of founding a Polish mission in Northern Persia in order to minister to the Caucasian tribes was created by a Polish Jesuit, Ignacy Zapolski. Yet, after the death of Sobieski, Zapolski's idea, which gained very limited support of the Commonwealth, could not be turned into reality.

Keywords: John III Sobieski, Crimean Khanate, Persia, Ottoman Empire, Jesuit missionaries, Ignacy Zapolski.

Słowa kluczowe: Jan III Sobieski, chanat krymski, Persja, Imperium Osmańskie, misjonarze jezuiccy, Ignacy Zapolski.

1 Artykuł powstał dzięki finansowaniu z grantu NCN nr 2017/27/B/HS3/00151 „«Wielka i Mała Rozbieżność» widziane przez szkła korporacji: mieszkańcy Europy Środkowo-Wschodniej w Azji w XVII wieku", kierowanego przez prof. dr. hab. Dariusza Kołodziejczyka.

Adres do korespondencji: nkrolikowska@uw.edu.pl 
Bogata literatura poświęcona polityce Jana III Sobieskiego wobec najbliższych Rzeczypospolitej państw muzułmańskich, czyli Imperium Osmańskiego, Chanatu Krymskiego i Persji, świadczy o dużym zainteresowaniu tym tematem pokoleń historyków. Opracowania doczekały się związane z polityką wschodnią działania dyplomatyczne króla, zabiegi o poparcie jego polityki zagranicznej w samej Rzeczypospolitej, a w końcu działania militarne w latach 1673-1676 i 1683-16962. Aby nie powielać już istniejących badań, w niniejszym artykule zrezygnowano ze szczegółowego opisu stosunków między Rzecząpospolitą a wspomnianymi trzema jej najbliższymi państwami muzułmańskimi w okresie panowania Sobieskiego. Praca jest próbą zrozumienia, jak Sobieski postrzegał rolę Chanatu Krymskiego i Persji w odniesieniu do prowadzonej polityki wobec Imperium Osmańskiego. Co sądził o wzajemnych stosunkach Imperium Osmańskiego i coraz bardziej zależnego od niego Chanatu Krymskiego? W jaki sposób próbował wykorzystać konflikty interesów między oboma państwami? Jakie widział możliwości ułożenia relacji z tymi sąsiadami? Następnie należy odnieść się do próby zawiązania przez Sobieskiego antytureckiego sojuszu z safawidzką Persją. W końcu warto poruszyć kwestię, jaką rolę odgrywali w tych planach katoliccy misjonarze, szczególnie ci z terenów Rzeczypospolitej.

Na potrzeby tego artykułu panowanie Sobieskiego zostało podzielone na następujące cztery podokresy: 1) lata 1674-1678 - od wstąpienia Jana Sobieskiego na tron do pokoju Gnińskiego; 2) lata 1678-1683 - od pokoju Gnińskiego do bitwy pod Wiedniem; 3) lata 1683-1686 - od bitwy pod Wiedniem do ratyfikacji pokoju Grzymułtowskiego; 4) 1686-1696 - od ratyfikacji pokoju Grzymułtowskiego do śmierci króla.

Gdy Sobieski obejmował tron polski w 1674 roku, miał pełną świadomość konsekwencji traktatu buczackiego dla Rzeczypospolitej. We wrześniu 1672 roku, jeszcze jako marszałek koronny i hetman wielki koronny, podczas negocjowania przyszłego traktatu w Buczaczu zwrócił uwagę podkanclerzemu Andrzejowi Olszowskiemu, że „jeżeli haracz pozwolemy, to już Turcy i samego króla Imci za hospodara mieć będą. Boć i Xsiążecia siedmiogrodzkiego Turcy królem zowią, a przecie nulla subiectionis

2 Bibliografie bogatej literatury poświęconej kwestiom polityki wschodniej za Sobieskiego zawierają m.in. następujące studia na temat różnych aspektów panowania króla: Z. Wój cik, Jan Sobieski, Warszawa 1983, s. 574-587; Król Jan III Sobieski i Rzeczpospolita w latach 1674-1683, red. D. Milewski, Warszawa 2016, s. 259-272; Jarzmo Ligi Świętej? Jan III Sobieski i Rzeczpospolita w latach 1684-1696, red. D. Milewski, Warszawa 2017, s. 295-308. Szczególną uwagę warto poświęcić studiom dotyczącym całokształtu stosunków polsko-osmańskich i polsko-krymskich, zawierającym wydania traktatów między wskazanymi państwami przygotowanymi przez Dariusza Kołodziejczyka: D. Kołodziejczyk, Ottoman-Polish Diplomatic Relations (15th-18th Century). An Annotated Edition of Ahdnames and Other Documents, Leiden-Boston 2000; D. Kołodziejczyk, The Crimean Khanate and Poland-Lithuania. International Diplomacy on the European Periphery (15 $15^{\text {th }}$ th Century): A Study of Peace Treaties Followed by Annotated Documents, Leiden-Boston 2011. Podobnie nie sposób pominąc wydania traktatów polsko-perskich opatrzonych szerokim wstępem, które przygotował wspomniany wyżej autor wraz ze Stanisławem Jaśkowskim i Piruzą Mnatsakanyanem: D. Kołodziejczyk, S. Jaśkowski, P. Mnatsakanyan, Stosunki dawnej Rzeczypospolitej z Persją Safawidów w świetle dokumentów archiwalnych, Warszawa 2017. 
od Hospodarów differentia"3. Dzięki brawurowej interwencji hetmana wielkiego koronnego w październiku 1672 roku na Lubelszczyźnie i Rusi Czerwonej udało się uniknąć w traktacie słowa „haracz”. Zamiast niego użyto mniej upokarzającego terminu „piszkesz” (pişkeş) - który tłumaczono na polski jako „,podarunek”. Niemniej, jak zauważył Dariusz Kołodziejczyk, w oczach Imperium Osmańskiego Rzeczpospolita dołączyła do państw wasalnych sułtana ${ }^{4}$. Kolejne kampanie Sobieskiego w latach 1673-1676 miały na celu zmianę tego stanu rzeczy oraz odzyskanie możliwie największej części utraconego Podola. Król nie uważał jednak, że należy walczyć o ich ponowne włączenie w granice polsko-litewskie za wszelką cenę. Po nieudanej kampanii żórawińskiej wysyłał do Stambułu wojewodę chełmińskiego Jana Gnińskiego z nadzieją odzyskania części utraconych ziem, ale zdawał sobie sprawę, że dygnitarze osmańscy mogą twardo negocjować, i dopuszczał możliwość uznania dużych strat terytorialnych w zamian za pokój. Jan III liczył także, że zakończona zawarciem traktatu misja Gnińskiego otworzy możliwość przyszłego antymoskiewskiego sojuszu z Wysoką Portą ${ }^{5}$. Te właśnie wytyczne znajdujące się w tajnej instrukcji dla posła z 7 maja 1677 roku mogą wskazywać, że Sobieski rozumiał, że życzenie odzyskania utraconych ziem wobec słabości militarnej Rzeczypospolitej miało małe szanse się spełnić.

Zgoda Sobieskiego na ustępstwa na froncie południowym wynikała z nowych możliwości, które otwierały się w polityce bałtyckiej. W latach 1674-1678 Sobieski widział szansę odzyskania Prus Książęcych w sojuszu z antyhabsburską koalicją tworzoną przez Ludwika XIV. Król Słońce przewidział w niej miejsce obok innych państw zarówno dla Rzeczypospolitej, jak i Turcji. W historiografii wskazuje się na różne powody, które stanęły na przeszkodzie ambitnym planom Jana III, takim jak niechęć szlachty do udziału w kolejnej, ryzykownej kampanii wojennej, niepowodzenia militarne armii szwedzkiej w walce z elektorem, zawarcie traktatów w Nijmegen już w 1678 roku $^{6}$, czyli wtedy, gdy Jan Gniński wrócił z zawartym w końcu traktatem pokojowym z Imperium Osmańskim.

Należy podkreślić, że jednym z ważniejszych negocjatorów prowadzącym rozmowy z Gnińskim w Stambule był nowo mianowany chan Murad Girej. Zachowane opisy tych negocjacji wskazują, że udział tatarskiego władcy nie przyniósł żadnych pozytywnych skutków dla Rzeczypospolitej. Chan zdawał się mieć bardzo jasny obraz słabości militarnej ówczesnego państwa polsko-litewskiego, czemu czasem dawał wyraz w sposób wysoce upokarzający dla Gnińskiego. W tych rozmowach

3 List z 15 IX 1672 roku marszałka i hetmana wielkiego koronnego Jana Sobieskiego do podkanclerzego koronnego Andrzeja Olszowskiego, Pisma do wieku i spraw Jana Sobieskiego, wyd. F. Kulczycki, t. 1, Kraków 1880, cz. 2, s. 1073.

4 D. Kołodziejczyk, Ottoman-Polish Diplomatic Relations (15th-18th Century)..., s. 148.

5 Źródła do poselstwa Jana Gnińskiego wojewody chełmińskiego do Turcyi w latach 1677-1678, wyd. F. Pułaski, Warszawa 1907, s. 206-207.

${ }_{6} \mathrm{Na}$ temat polityki północnej Sobieskiego por. m.in.: A. Kamieński, Polska a Brandenburgia-Prusy w drugiej polowie XVII wieku. Dzieje polityczne, Poznań 2002, rozdział III; J. Woliński, Sprawa pruska 1673-1675 i traktat jaworowski [w:] idem, Z dziejów wojny i polityki w dobie Jana Sobieskiego, Warszawa 1960, s. 16-56; C. Clarke, Iron Kingdom: The Rise and Downfall of Prussia, 1600-1947, Cambridge 2006. 
Murad Girej jawi się również jako polityk pozbawiony złudzeń dotyczących możliwości prowadzenia przez Chanat niezależnej od Imperium Osmańskiego gry na arenie międzynarodowej, mającej polegać na poparciu ustępstw terytorialnych wobec Rzeczypospolitej na Podolu? ${ }^{7}$ Zdecydowanie negatywna postawa Murada Gireja wobec polskiego posła stoi w kontraście do działań dwóch jego poprzedników panujących w drugiej połowie XVII wieku: Mehmeda IV Gireja, którego drugie rządy przypadły na lata 1654-1666, i Selima Gireja, który po raz pierwszy zasiadał na tronie w latach 1671-1677. Dariusz Kołodziejczyk ostatnio podsumował, że według wcześniejszych historyków wiele wskazuje na to, że obaj powyżej wspomniani władcy tatarscy świadomie prowadzili politykę utrzymania równowagi sił w północnym basenie Morza Czarnego, co w trzeciej ćwierci XVII wieku oznaczało konieczność poparcia słabnącej Rzeczypospolitej ${ }^{8}$.

Sobieski, uczestnik wielu kampanii prowadzonych w sojuszu z Tatarami podczas tak zwanego długiego aliansu między chanem a Rzecząpospolitą $\mathrm{w}$ latach 1654-1667, mógł śledzić sytuację w Chanacie w okresie panowania Mehmeda IV Gireja, gdy Wysoka Porta sprawowała nad Tatarami słabszą kontrolę ze względu na konieczność uporania się z serią problemów wewnętrznych. Król obserwował więc chana, realizującego dość niezależną od Wysokiej Porty politykę północną obliczoną na osłabienie Moskwy, a wzmocnienie Rzeczypospolitej. Osmański podróżnik Ewlija Czelebi, który w latach 60. XVII wieku odwiedził Krym i był świadkiem detronizacji Mehmeda IV Gireja ${ }^{9}$, w swoich Księgach podróży pisał wprost o przyjaźni łączącej tego władcę krymskiego z królem polskim ${ }^{10}$. Korzystna, chociaż kosztowna ${ }^{11}$ dla Rzeczypospolitej polityka krymska zakończyła się wraz z detronizacją Mehmeda IV Gireja, którego zastąpił całkowicie zależny od Porty Adyl Girej. W latach 1667-1671 był on posłusznym realizatorem nowej polityki północnej Imperium Osmańskiego, zakładającej dużo większe zaangażowanie osmańskie na stepach czarnomorskich i w związku z tym ograniczenie władzy chanów na tych terenach ${ }^{12}$. Poseł Sobieskiego, Jan Karwowski, który w przededniu wyprawy buczackiej przybył na Krym, informował hetmana w liście datowanym na 24 grudnia 1671 roku o tym,

7 Źródła do poselstwa Jana Gnińskiego..., s. 64-80, 123-125, 298-301.

8 D. Kołodziejczyk, Das Krimkhanat Als Gleichgewichtsfaktor in Osteuropa (17.-18. Jahrhundert) [w:] The Crimean Khanate Between East and West (15th-18th Century), Hrsg. D. Klein, Wiesbaden 2012, s. 47-58.

9 Księga podróży Ewliji Czelebiego (Wybór), red. Z. Abrahamowicz, tłum. Z. Abrahamowicz, A. Dubiński, S. Płaskowicka-Rymkiewicz, Warszawa 1969, s. 333-337, 362.

10 N. Gemici, Evliya Çelebi'ye Göre II. Viyana Muhasarasında Kırım Hanı'nın Yanlış Tutumu Sebepleri [Powody niewłaściwego zachowania chana krymskiego podczas drugiego oblężenia Wiednia według Ewliji Czelebiego], „Türkiyat Mecmuası” 2016, C. 26, S. 1, s. 131-146, szczególnie s. 142-145.

$11 \mathrm{Na}$ temat wymiernych kosztów finansowych poniesionych na rzecz aliansu z Chanatem przez Rzeczpospolitą zob.: Z. Wójcik, Some Problems of Polish-Tatar Relations in the Seventeenth Century. The Financial Aspects of the Polish-Tatar Alliance in the Years 1654-1666, „Acta Poloniae Historica” 1966, R. 13, s. 87-102.

12 The Ottoman Survey Register of Podolia (ca. 1681). Defter-i Mufassal-i Eyalet-i Kamaniçe, vol. 1, ed. D. Kołodziejczyk, Cambridge, MA 2004, s. 3-5. 
jak niechętnie Tatarzy idą na wyprawę przeciw Rzeczypospolitej. Nowy chan Selim Girej miał mu w sekrecie powiedzieć:

[...] i ja z duszy żałuję straty przyjaźni waszej [...] mam znajomość i przyjaźń wielką ze wszystkimi Waszymi Pany, a osobliwie z marszałkiem [Janem Sobieskim], z którym byłem tak długi czas na wojnie w Ukrainie. A cóż mam czynić? Nie moja wola, Cesarza [Mehmeda IV] Pana mego wola, z której łaski osiadłem na te tu państwo. A do tego, wierz mi, coć powiem, tylko mnie nie wydawaj, że kiedy bym widział was tak mocnych, jakoście bywali przedtem, tedy bym stanął przy was, i rzekłbym: stój Cesarzu, nie winni nic Polacy, są to przyjaciele nasi, dotrzymują nam i we złym, i w dobrym. Tak bym rzekł i cały Krym, bo i oni wolności siła mają od Porty naruszonych. Ale kiedy słyszę i widzę was tak ubogich i słabych, i niemających przyjaciół, cóż mam czynić? [...] Długo się Porta na Was gotowała i z dawna, ale albo my rozradzali, albośmy ich straszyli, żeście możni, żeście bogaci. Ale teraz, gdy się w Was wpatrzyli, cale Was sobie lekceważą, i mówią, że jednego roku po samą Warszawę i Kraków państwa wasze odbiorą ${ }^{13}$.

Selim Girej doskonale zdawał sobie sprawę, że umocnienie się Imperium Osmańskiego na Ukrainie oznacza osłabienie wpływów krymskich w regionie, a przede wszystkim odcięcie Tatarom źródła pozyskiwania niewolników. $Z$ tego względu zgodził się na prośbę Michała Korybuta Wiśniowieckiego na podjęcie próby mediacji między Rzecząpospolitą a Wysoką Portą w 1672 roku. Utrata Kamieńca Podolskiego na rzecz Turcji mogła jednak tylko umocnić przekonanie chana o słabości Rzeczypospolitej, a co za tym idzie - o braku potencjalnego sojusznika, który mógłby pomóc ograniczyć rosnące wpływy osmańskie na północy Morza Czarnego. W związku z tym - co dokładnie opisał Zbigniew Wójcik - przekonywał polskich dygnitarzy, że konieczne jest uznanie osmańskich nabytków terytorialnych na Ukrainie ${ }^{14}$. Trudne położenie chana i dylematy polityki tatarskiej rozumiał w pełni Sobieski, czemu dał wprost wyraz, pisząc w liście wysłanym w poselstwie na Krym w 1674 roku: „,czym Rzeczpospolita mocniejsza, tem Krym w większym u Porty respekcie"15.

Selim Girej stracił tron na rzecz Murada Gireja po niepowodzeniu pierwszej wyprawy czehryńskiej w 1677 roku. Jak już wspomniano, w materiałach dotyczących poselstwa Gnińskiego maluje się obraz tatarskiego władcy pozbawionego iluzji na temat sił Chanatu w porównaniu z Imperium Osmańskim. W odróżnieniu od swojego poprzednika $\mathrm{w}$ żaden sposób nie dystansował się wobec polityki Porty, nie przypominał niedawnego sojuszu z lat $1654-1666 \mathrm{w}$ rozmowach z polskim posłem. Przeciwnie, upokarzał go i groził mu nawet więzieniem. Słowem, wyłaniał się obraz chana marionetki, który podobnie jak Adyl Girej był skłonny wykonywać polecenia Wysokiej Porty.

Tymczasem późniejsze źródła przypisują Muradowi Girejowi dążenie do wzmocnienia pozycji Chanatu wobec Imperium Osmańskiego, a niektóre wskazują także na sabotowanie wyprawy wiedeńskiej. Według Seyyida Mehmeda Rizy, autora kroniki

13 Pisma do wieku i spraw Jana Sobieskiego, t. 1, cz. 1, s. 748-749.

14 Z. Wójcik, Mediacja tatarska między Polska a Turcja w roku 1672, „Przegląd Historyczny” 1962, R. 53, nr 1, s. 145.

15 J. Woliński, Pośrednictwo tatarskie w wojnie polsko-tureckiej 1674-1675, „Polityka Narodów” 1934, R. 4, s. 11-33. 
Chanatu z pierwszej połowy XVIII wieku ${ }^{16}$, Murad Girej zamierzał osiągnąć większą niezależność swojego państwa od Turcji poprzez reformę systemu prawnego Chanatu, to jest odrzucenie prawa muzułmańskiego, którego rozwiązania zastosowane na Krymie były wzorowane na modelu przyjętym w Imperium Osmańskim. Z tego względu, zdaniem kronikarza, odrzucenie szariatu i powrót do stosowania mongolskiego prawa zwyczajowego miały być równoznaczne ze zminimalizowaniem wpływów osmańskich w Chanacie. Zgodnie z dalszą narracją Seyyida Mehmeda Rizy chan szybko musiał się jednak wycofać $\mathrm{z}$ ambitnych planów reform ze względu na protesty poddanych. Ostatecznie miał zostać przekonany do zmiany zdania przez samego Vani Mehmeda Efendiego, słynnego derwisza i ulubionego kaznodzieję sułtana Mehmeda $\mathrm{IV}^{17}$. Żadne inne źródła narracyjne, a co ważniejsze - zachowane krymskie księgi sądowe $\mathrm{z}$ tego okresu ${ }^{18}$ nie potwierdzają przytoczonej historii. Odsuwając na bok rozważania na temat powodów włączenia jej do kroniki przez Seyyida Mehmeda Rizę, warto podkreślić, że omówiony przekaz świadczy, że zachowała się pamięć o Muradzie Gireju jako o władcy, który próbował zmniejszyć wpływy osmańskie na Krymie, a także o napięciach w stosunkach między imperium i chanatem w okresie tuż przed wyprawą wiedeńską.

Udział wojsk tatarskich w tym konflikcie militarnym był różnie oceniany w źródłach muzułmańskich. Podczas gdy część osmańskich kronikarzy, takich jak Silahdar Mehmed Aga, Defterdar Sary Mehmed Pasza czy Dżebedżi Hasan Esiri, uważała, że zaniedbania Murada Gireja przyczyniły się do klęski wojsk muzułmańskich, inni między innymi Huseyn Hezarfen - wyrazili opinię, że Kara Mustafa Pasza próbował zrzucić całą winę na chana, usuwając go z tronu zaraz po przegranej bitwie ${ }^{19}$. Odpowiedzialnością za niepowodzenie wyprawy obarczał wielkiego wezyra również żydowski kronikarz z Budy, Isaak ben Zalman Schulhof, którego dzieło powstało krótko po 1688 roku. Sugerował on, że Kara Mustafa Pasza celowo opóźnił ostateczny atak na Wiedeń ze względów finansowych, to znaczy aby żołnierze nie plądrowali zdobytego miasta, do czego mieliby prawo zgodnie z prawem muzułmańskim, tylko aby wszystkie zdobycze stały się własnością skarbu osmańskiego ${ }^{20}$. Także kronikarze

16 Więcej na temat Seyyida Mehmeda Rizy zob.: N. Seyyityahya, Proishoždenie Seiida Muhammeda Rizy (k voprosu o meste ego «Semi planet》 sredi proizvedenii krymskoi istoričeskoi prozy XVIII veka), „Kultura Narodov Prichernomora” 2003, C. 44, s. 35-41; I. Zaicev, Krymskaia istoriografičeskaia tradicia XV-XIX vekov, Moskva 2009, szczególnie s. 95-121.

17 Essebüsseyyar ili sem 'planet soderžavščii istoriu krymskix xanow ot Mengli Girej Xana pierwogo do Mengli Girej Xana vtorogo t. e. s 871/1466 po 1150/1737, sost. Mirza Kazembeg, Kazan 1832, s. 184-186; R. Počekaev, Kırım Hanı Murat Giray'ın Adlı Reformu [Reformy prawne chana Murada Gireja], „Belleten” 2011, C. 75, s. 571-578.

18 Rossiiskaia Natsional'naia Biblioteka w Petersburgu, Otdel Rukopisev, Fond 917, krymskie księgi sądowe nr 22, 23a i b, 25.

19 Podczas gdy osmańscy kronikarze tacy jak Silahdar Mehmed Aga, Defterdar Sary Mehmed Pasza czy Dżebedżi Hasan Esiri uważali, że zaniedbania Murada Gireja przyczyniły się do klęski wojsk muzułmańskich, inni - m.in. Huseyn Hezarfen - sądzili, że Kara Mustafa Pasza przez zmianę chana zaraz po przegranej bitwie próbował zrzucić na niego całą winę (Kara Mustafa pod Wiedniem, red. i tłum. Z. Abrahamowicz, Kraków 1973, s. 200, 233, 258, 298).

20 I. Schulhoff, Megilat Oven, red. i thum. P. Ago stino, Roma 1982, s. 35. Do podobnych wniosków doszedł Zygmunt Abrahamowicz, który badał finansowe aspekty osmańskiej wyprawy pod Wiedeń, 
krymscy różnili się między sobą w opiniach o przyczynach klęski pod Wiedniem. Abdulgaffar el-Kyrymi, który sprawował kilka drobniejszych urzędów w Chanacie w pierwszej połowie XVIII wieku, napisał w swoim dziele Esencja historii, że to Murad Girej przyczynił się do niepowodzenia wyprawy ${ }^{21}$. Seyyid Mehmed Riza i Mehmed Girej, który był krewnym Murada Gireja i sam uczestniczył w wyprawie, podkreślili za to, że oskarżenia wobec chana były bezpodstawne i został on bez powodu pozbawiony tronu ${ }^{22}$. Wobec tak rozbieżnych opinii zawartych w źródłach muzułmańskich warto raz jeszcze odnotować ustalenia Czesława Chowańca i Zbigniewa Wójcika, że Tatarzy unikali starcia podczas bitwy wiedeńskiej, w której walczyli na prawym skrzydle przeciw wojskom Rzeczypospolitej ${ }^{23}$. Podobnie zachowali się w bitwie pod Parkanami, gdy dowodził nimi nowy chan Hadży Girej, na co zwrócił uwagę w liście do Marysieńki sam Sobieski ${ }^{24}$.

Powściągliwe zachowanie Tatarów w obu starciach skłoniło Sobieskiego do ponowienia prób uzyskania neutralności Chanatu, a być może nawet pozyskania Tatarów do sojuszu antyosmańskiego. Już w styczniu 1684 roku na radzie senatu wysunięto pomysł wysłania poselstwa do chana. W 1685 roku z ramienia Rzeczypospolitej misję przeprowadził Tomasz Golczewski, który negocjował z powracającym na tron Selimem Girejem. Poseł polski miał wykorzystać wiedzę o tatarskim poczuciu wyższości, chanowie byli przecież potomkami Czyngis-chana. Sobieski kazał swojemu posłowi życzyć krymskiemu władcy, aby niewolnicy (NKr-J - czyli osmańscy dygnitarze, których rekrutowano spośród odpowiednio wykształconych niewolników) nie panowali dłużej nad wolnym, dumnym i starożytnym narodem ${ }^{25}$. W zamian za neutralność w wojnie z Imperium Osmańskim Sobieski obiecywał obronę niezależnego statusu Krymu przez cesarza, Wenecję i Rzeczpospolitą. Jak

por. Z. Abrahamowicz, Tło polityczne i ekonomiczne wyprawy wiedeńskiej Kary Mustafy, „Kwartalnik Historyczny" 1983, R. 90, s. 21-54.

21 Abdulgaffar Kyrymi, Umdet al-akhbar, trans. D.D. Pashaoglu, Kazan 2014, s. 147. Więcej o Abdulgaffarze el-Kyrymim por. B. Kellner-Heinkele, Who Was 'Abdulghaffar el-Qirimi? Some Notes on an 18th Century Crimean Tatar Historian, „Journal of Asian History” 1998, vol. 32, no. 2, s. 145-156; N. Seyyityahya, Učebnyi iz Karasu Abdul'gaffar Kyrymi i ego istoričeskoe cočinienie [w:] Čoban-zade. Sbornik materialov I krymskoi mežnunarodnoi konferencii. Belogorsk (Karasubazar), 23-25 maja 2012 g., sost. A.R. Emirov, Symferopol 2013, s. 222-242; I. Zaicev, op. cit., szczególnie s. $178-189$.

22 Der Tarih-i Mehemmed Giray - Eine Osmanische Quelle zur Belagerung Wiens durch die Türken im Jahre 1683, red. i tłum. M. Köhbach, „Zeszyty Naukowe Uniwersytetu Jagiellońskiego. Prace Historyczne" 1983, R. 75, s. 154.

23 C. Chowaniec, Sobieski wobec Tatarszczyzny 1683-1685, „Kwartalnik Historyczny” 1928, R. 42, s. 54; Z. Wójcik, Jan Sobieski, s. 371.

${ }^{24}$ „Tatarów w tej okazji nie było, tylko kilkaset, dlatego wymyśleć tego nie podobna, choć są o mil kilka od nas. Widzę, że się i nowy chan z nami bić nie chce, jako i stary. Ja jednego więźnia Tatara poślę do niego z komplementem, że tak na nas dyskretny i przyjaźni z nami łamać nie chce", list Sobieskiego do żony z 10 X 1683 [w:] Jan Sobieski, Listy do Marysieńki, oprac. L. Kukulski, Warszawa 1962, s. 558. Niechęć Murada Gireja i Hadży Gireja do walki w kampanii lat 1683-1684 odnotowały także źródła rosyjskie, por. K. Koczegarow, Rzeczpospolita a Rosja 1680-1686. Zawarcie traktatu o pokoju wieczystym, red. T. Szwaciński, Warszawa 2017, s. 292.

25 C. Chow aniec, Sobieski wobec Tatarszczyzny 1683-1685, s. 60-61. 
dokładnie opisali Czesław Chowaniec i Witold Wasilewski, na podstawie relacji przebiegu misji Golczewskiego zawartej w liście polskiego misjonarza, jezuity Pawła Kostaneckiego $^{26}$, z Krymu, obfitowała ona w dramatyczne zwroty akcji. Na początku posłowi grożono więzieniem, następnie doczekał się przychylnej, prywatnej audiencji u chana, aby na końcu otrzymać uprzejmą odprawę, w której Tatarzy nie podjęli żadnych zobowiązań oczekiwanych przez stronę polskąa ${ }^{27}$. Zarówno Chowaniec, jak i Wasilewski doszukują się niepowodzeń misji Golczewskiego w nierealnych oczekiwaniach polskiej dyplomacji, za które uważają nadzieje na przystąpienie Chanatu do sojuszu antyosmańskiego z Rzecząpospolitą, która pozostawałaby w aliansie z Moskwą. Wypada zgodzić się z Wasilewskim, że w ostatniej ćwierci XVII wieku Chanat, jakkolwiek niechętnie patrzył na wzmocnienie Turcji na północnym wybrzeżu Morza Czarnego, bardziej obawiał się rosnącej potęgi Rosji. Kyrył Koczegarow, podobnie jak wyżej wspomniani historycy polscy, podkreślił, że Chanat był zainteresowany sojuszem z Rzecząpospolitą jedynie, gdyby był on wymierzony w Moskwę ${ }^{28}$. Kiedy nieudane kampanie lat 1685 i 1686 zmusiły Sobieskiego do ratyfikacji wynegocjowanego kilka miesięcy wcześniej tak zwanego pokoju Grzymułtowskiego z Rosją, szansa na sojusz z Tatarami została zaprzepaszczona, a plany ograniczenia wpływów osmańskich na Krymie stały się zupełnie nierealne. Alians z Rosją spowodował zaostrzenie polityki Sobieskiego wobec Tatarów. Po 1686 roku król starał się w kampaniach wyprzeć ich z terenów księstw naddunajskich, okazywał też większą nieufność wobec dyplomacji tatarskiej. Po nieudanej dla wojsk polsko-litewskich kampanii w Mołdawii w 1691 roku chan Safa Girej wysłał posła z ofertą mediacji między Rzecząpospolitą a Imperium Osmańskim. Propozycję tę, która zakładała oddanie Podola przez Wysoką Portę, Sobieski potraktował jednak nie jako próbę doprowadzenia do rozejmu między oboma państwami, ale jako wysiłek zmierzający do skłócenia państw Ligi Świętej. Mimo niepowodzenia tej misji powracający po raz kolejny na tron krymski Hadży Selim Girej ponownie próbował doprowadzić do pokoju polsko-osmańskiego w 1693 roku. Żądania terytorialne Rzeczypospolitej, które dotyczyły nie tylko Podola, ale także kontrolowanej przez wojsko polsko-litewskie północnej Mołdawii, doprowadziły do porażki również tej, ostatniej już w okresie panowania Sobieskiego, mediacji tatarskiej ${ }^{29}$.

Chanat Krymski nie był jedynym państwem muzułmańskim, które Sobieski miał nadzieję pozyskać do sojuszu antyosmańskiego. Pierwsze próby przekonania Persji do uderzenia na Imperium Osmańskie podjął jeszcze jako hetman wielki i marszałek wielki koronny w 1673 roku, gdy wysłał list do szacha Sulejmana przez hiszpańskiego

26 Więcej na temat Pawła Kostaneckiego por. Pawet Kostanecki [w:] Encyklopedia wiedzy o jezuitach na ziemiach Polski i Litwy 1564-1995, oprac. SJ L. Grzebień, Kraków 1996, s. 308-309; M. Miazek-Męczyńska, Indipetae Polonae - kolatanie do drzwi misji chińskiej, Poznań 2015, s. 17, 90, 137, 144, 157-158.

27 List Pawła Kostaneckiego do Jana III Sobieskiego z 12 lipca 1685 roku, AGAD, Archiwum Publiczne Potockich, 47, t. 1. fol. 268-270; C. Chowaniec, Sobieski wobec Tatarszczyzny 1683-1685, s. 62-64; W. Wasilewski, Wyprawa bukowińska Stanistawa Jabłonowskiego w 1685 roku, Warszawa 2002, s. 49-51.

${ }^{28}$ K. Koczegarow, op. cit., s. 123.

29 D. Kołodziejczyk, The Crimean Khanate and Poland-Lithuania..., s. 193-194. 
duchownego Pedro Cubera Sebastiana. Nalegania Sobieskiego, podobnie jak misja rosyjska A. Priklonskiego i K. Kristoforowa z 1674 roku, nie skłoniły jednak Persji do rozpoczęcia wojny z północnym sąsiadem ${ }^{30}$. Zdaniem Rudiego Mattheego decyzja dworu safawidzkiego miała ściśle racjonalne uzasadnienie, a nie wynikała jak sugerowały to wielokrotnie źródła europejskie - ze słabego charakteru szacha ${ }^{31}$. Matthee zwrócił uwagę, że w odpowiedzi na propozycje polską i rosyjską wielki wezyr perski Szejch Ali Chan wyraził gotowość włączenia się do wojny, gdy oba państwa rozpoczną działania militarne, ale pozwolił sobie także na gorzką uwagę, że chrześcijanie wielokrotnie proponowali Persji sojusz antyosmański, po czym bez uprzedzenia muzułmańskiego sojusznika zawierali pokój z Wysoką Portą. Badacz podsumował, że dwoma najważniejszymi powodami, które przesądziły o neutralności Persji w konflikcie, były brak zaufania dla strony europejskiej oraz przekonanie, że decydująca przewaga państw chrześcijan nad Imperium Osmańskim niebezpiecznie zakłóciłaby równowagę sił $\mathrm{w}$ regionie ${ }^{32}$.

Podobnie jak w latach 70. XVII wieku brakiem sukcesu zakończyły się działania dyplomatyczne w Persji podejmowane przez Jana III zaraz po zwycięstwie wiedeńskim $^{33}$. Francuski misjonarz Raphaël du Mans, który w tym okresie thumaczył europejską korespondencję na potrzeby dworu perskiego, relacjonował, że początkowo szach pozostawał pod tak wielkim wrażeniem zwycięstwa wiedeńskiego, że zaczął rozważać przygotowanie kampanii, aby odzyskać Bagdad ${ }^{34}$. Jednak udana osmańska akcja dyplomatyczna w połączeniu ze wspomnianym powyżej podejściem perskim do sił chrześcijańskich spowodowały, że szach postanowił zachować neutralnośćc ${ }^{35}$. Do działania nie przekonało go poselstwo Bohdana Grudzieckiego z 1684 roku ani też wysłana kilka miesięcy później uroczysta misja w imieniu Rzeczypospolitej i Wenecji, powierzona Ormianinowi Salomonowi Konstantemu Syri Zgórskiemu ${ }^{36}$. Dwa lata później znów ten sam dyplomata wyruszył do Persji, aby reprezentować obok Rzeczypospolitej i Wenecji także Cesarstwo i Papiestwo. Również to okazałe poselstwo, które zostało uroczyście przyjęte przez szacha, nie przyniosło wymiernych rezultatów ${ }^{37}$.

Niepowodzenia dotychczasowych działań dyplomatycznych nie zniechęciły Sobieskiego do podtrzymywania kontaktów dyplomatycznych z Isfahanem. W ostatniej

30 R. Matthee, Persia in Crisis. Safavid Decline and the Fall of Isfahan, London-New York 2012, s. 131.

31 A Chronicle of the Carmelites in Persia. The Safavids and the Papal Mission of the $17^{\text {th }}$ and $18^{\text {th }}$ Centuries, vol. 1, ed. H. Chick, London 2012 [reprint], s. 405-469, szczególnie s. 405-411.

32 R. Matthee, Persia in Crisis..., s. 132-133.

33 D. Kołodziejczyk, S. Jaśkowski, P. Mnatsakanyan, op. cit., s. 38-39.

${ }_{34}$ Persja straciła po raz drugi Bagdad, który szach Abbas I odzyskał w 1624 roku, w wyniku długiego oblężenia przez armię osmańską w 1638 roku.

35 R. Matthee, Persia in Crisis..., s. 133-134.

36 K. Stopka, Syri (Siri, Siriensis, Siricki de Syri) Zgórski (Zgorski, Zgurski) Salomon [w:] Polski stownik biograficzny [dalej: PSB], t. XLVI, s. 285-288; C. Chow aniec, Z dziejów polityki Jana III na Bliskim Wschodzie 1683-1686, „Kwartalnik Historyczny” 1926, R. 40, s. 151-160.

37 S. Brzeziński, Misjonarze i dyplomaci polscy w Persji w XVII i XVIII wieku, Potulice 1935, s. $35-36$. 
dekadzie swojego panowania król wysłał jeszcze raz Zgórskiego (w 1688 roku), a towarzyszyli mu francuscy jezuici: Philippe Avril ${ }^{38}$ i Antoine de Beauvollier, oraz trzej polscy jezuici: Ignacy Franciszek Zapolski, Konrad Terpiłowski i Jan Gostkowski, który miał podjąć działalność misyjną w Imeretiii ${ }^{39}$. Avril i de Beauvollier żywili nadzieję, że dzięki ustaleniom pokoju Grzymułtowskiego uda im się w towarzystwie polskiego posła przebyć część terytorium rosyjskiego, a następnie wraz z dwoma wyznaczonymi do tego polskimi misjonarzami, czyli Zapolskim i Terpiłowskim, przez Syberię dotrzeć do Chin. W Moskwie misjonarze spotkali się jednak z niezwykle chłodnym przyjęciem: Francuzom nie tylko odmówiono przejazdu drogą lądową na wschód, lecz także zawrócono ich do Rzeczypospolitej, a Polakom, którzy nie chcieli wracać do domu, pozwolono wyruszyć w dalszą drogę jedynie do Persji ze Zgórskim $^{40}$. Polski poseł pozostał przy dworze w Isfahanie jako rezydent aż do śmierci w 1690 roku. Ojciec Zapolski objął wówczas funkcję posła polskiego przy dworze perskim. Oprócz podejmowania dalszych działań zmierzających do zawarcia sojuszu antyosmańskiego misjonarz wiele uwagi poświęcił rozwijaniu misji jezuickiej na północy Persji. Zainteresowanie tym regionem jako centrum misyjnym stanowiło kontynuację polityki Zgórskiego, który jeszcze w 1683 roku raportował do Kongregacji Propagandy Wiary o konieczności zwiększenia działalności misyjnej w Szemasze, mieście leżącym na szlaku przejazdów poselstw europejskich, zamieszkałym przez Ormian, którzy zdają się otwarci na ideę konwersji na katolicyzm ${ }^{41}$. Kilkakrotnie Zgórskiemu udało się uzyskać od Jana III wsparcie finansowe dla francuskiej misji jezuickiej w tym mieście ${ }^{42}$. Zapolski, tak jak wielu innych ówczesnych misjonarzy, pragnął nie tyle wspierać ośrodek założony przez inny zakon lub przez zakonników z innego państwa ${ }^{43}$, ile dążył do założenia misji podległej swojej narodowej prowincji. Uważał, że dobra będzie do tego celu nieodległa od Szemachy Gandża ${ }^{44}$. Nie zrażał go fakt, że w tym mieście działali już włoscy kapucyni ${ }^{45}$. Twierdził, że

38 Więcej na temat ojca Philippe'a Avrila i jego trzech nieudanych prób dotarcia do Chin w latach 1685-1698 zob.: M. Miazek-Męczyńska, op. cit., s. 144; F. Vermote, Passage Denied! Dangers and Limitations of Jesuit Travel Throughout Eurasia During the Seventeenth and Eighteenth Centuries, http://worldhistoryconnected.press.illinois.edu/10.3/forum_vermote.html (dostęp: 30.05.2018).

39 B. Natoński, J. Poplatek, Jan Gostkowski [w:] PSB, t. XLVI, s. 359-360.

40 M. Bednarz, Ignacy Franciszek Zapolski SI. Dyplomata i misjonarz w Persji pod koniec XVII w. [w:] F.A. Plattner, Gdy Europa szukała Azji, tłum. M. Bednarz, A. Starzeński, Kraków 1975, s. 372 378; J. Krzyszkowski, Entre Varsovie et Ispahan. Le P. Ignace-François Zapolski S.I., „Archivum Historicum Societatis Jesu" 1949, R. 18, s. 85-117.

${ }^{41}$ Archivio Storico di Propaganda Fide [Archiwum Historyczne Kongregacji ds. Propagandy Wiary] w Rzymie [dalej: APF], Scritture referite nei Congressi, t. 1, Georgia, fol. 329 r-v.

42 M. Bednarz, op. cit., s. 379.

43 Więcej na temat rywalizacji między misjonarzami z różnych zakonów, a nawet misjonarzami z tych samych zakonów, ale z innych prowincji, którzy działali w ówczesnej Persji, zob. R. Matthee, Poverty and Perseverance: The Jesuit Mission of Isfahan and Shamakhi in Late Safavid Iran, „Al-Qantara" 2015, vol. 36, s. 463-501.

${ }^{44}$ List Ignacego Zapolskiego do Kongregacji Propagandy Wiary, 4 IV 1697, APF, Scritture originali referite nelle Congregatione, t. 527, fol. $321 \mathrm{r}-322 \mathrm{v}$.

45 List Ignacego Zapolskiego do Kongregacji Propagandy Wiary, 5 IV 1697, APF, Scritture originali referite nelle Congregatione, t. 527, fol. 320r-v. Na temat skarg kapucynów do Kongregacji Propagandy 
misjonarze z Rzeczypospolitej szczególnie świetnie nadają się do chrystianizowania terenów na północ od Persji, ponieważ Polacy są przyzwyczajeni do trudnych warunków klimatycznych, a także mają wspólne doświadczenia - mieszkańcy obu terytoriów cierpieli w wyniku najazdów Tatarów krymskich ${ }^{46}$.

Kilka czynników wpłynęło na niepowodzenie realizacji ambitnych planów Zapolskiego o założeniu polskiej placówki misyjnej. Wydaje się, że brak politycznego i finansowego wsparcia Rzeczypospolitej po śmierci Sobieskiego był jednym z najważniejszych powodów. $Z$ tych samych względów nie udało się polskim trynitarzom, których Jan III sprowadził do Rzeczypospolitej w 1685 roku, uzyskać prawa do prowadzenia placówki na Krymie. Starania o to polska gałąź zakonu rozpoczęła jeszcze za życia króla, w 1695 roku, i początkowo Kongregacja Propagandy Wiary była skłonna je poprzeć. Po długich rozważaniach Rzym zezwolił w końcu dwóm polskim braciom z Kamieńca Podolskiego na wyruszenie na Krym w 1707 roku. Wskazani misjonarze, świetnie przygotowani językowo do misji, nigdy jednak nie zebrali dostatecznych środków finansowych, aby dotrzeć na półwysep. W końcu w wyniku zgrabnej dyplomacji Ludwika XIV prowadzenie misji katolickiej na Krymie Kongregacja przydzieliła francuskim jezuitom, którzy mogli liczyć na wsparcie rezydenta francuskiego w Stambule, a później stałego konsula tego państwa w Bachczysaraju ${ }^{47}$.

\section{$* * *$}

Rozważając rolę Chanatu Krymskiego i Persji w polityce Jana III Sobieskiego wobec Imperium Osmańskiego, niewątpliwie należy zwrócić uwagę na wielokrotnie powtarzane przez króla próby pozyskania tych państw do sojuszu antyosmańskiego ${ }^{48}$. Działania dyplomatyczne skierowane wobec Tatarów zdają się mieć źródło w słusznym przekonaniu Sobieskiego, zrodzonym jeszcze w okresie długiego aliansu polsko-tatarskiego, o istnieniu tarć między Wysoką Portą a Chanatem i ich wykluczających się interesów. Niepowodzenia polityki króla należałoby upatrywać w niedocenieniu przez niego faktu, że sprzeczne $\mathrm{z}$ interesami Chanatu i prowadzoną przez niego polityką równowagi sił było włączenie Moskwy do ewentualnego aliansu polsko-tatarskiego. Chanowie niechętnie patrzyli na obecność osmańską na Podolu, ale także obawiali się zbytniego wzmocnienia Rosji kosztem Imperium Osmańskiego. Słabość militarna Rzeczypospolitej, widoczna w kampaniach lat 1685, 1685 i 1691,

Wiary na działalność polskich jezuitów w Gandży zob. list Bernardino Saluzzo do Kongregacji Propagandy Wiary, [brak daty, luty 1704?], Scritture referite nei Congressi, t. 1, Georgia, fol. 485.

46 List Ignacego Zapolskiego do Kongregacji Propagandy Wiary, 4 IV 1697, APF, Scritture originali referite nelle Congregatione, t. 527, fol. 321r-322v.

47 N. Królikowska, Polish-Lithuanian Missionaries in the Crimea and in the Northern Caucasus in the 17th Century [w:] Türkiye-Polonya Ilişkilerinde "Temas Alanlarl" (1414-2014) Uluslararast Konferansı Bildiler Kitabı, haz. N. Królikowska, H. Topaktaş, Ankara 2017, s. 403-413; Z. Madej, Z dziejów misji polskiej na Krymie, „Sacrum Poloniae Millenium” 1958, R. 5, s. 521-538. M. Inglot, Misjonarze jezuiccy na Krymie od poczatku XVII do połowy XVIII wieku [w:] Polacy na Krymie, wyd. E. Walewander, Lublin 2004, s. 177-204.

48 Warto pamiętać także o próbach Sobieskiego zawarcia aliansu z Kałmukami, zob. D. Kołodziejczyk, Tibet in the Crimea? Polish Embassy to the Kalmyks of 1653 and a Project of an AntiMuslim Alliance, „Acta Poloniae Historica” 2016, R. 114, s. 250-251. 
mogła skłaniać Tatarów do wniosku, że w przypadku nadmiernego osłabienia Wysokiej Porty Rzeczpospolita nie będzie stanowiła przeciwwagi dla rosnącej w siłę Moskwy. Misje dyplomatyczne Sobieskiego do Persji nie zakończyły się sukcesem, szach ostatecznie zachował neutralność wobec Imperium Osmańskiego. Taka decyzja Sulejmana i jego wielkiego wezyra Szejcha Alego Chana mogła wynikać z przekonania, że zbytnio wzmocnione państwa chrześcijańskie po ewentualnej porażce Wysokiej Porty zagrożą w końcu samej Persji. Safawidzki władca, podobnie jak chan krymski, zdawał się więc powstrzymywać przed wejściem do antyosmańskiej koalicji, aby nie naruszyć równowagi sił $\mathrm{w}$ regionie.

Interesującym wątkiem związanym z polityką dyplomatyczną Sobieskiego wobec Chanatu i Persji jest kwestia planów misyjnych polskich zakonników. Zwraca uwagę, że Jan III starał się wesprzeć finansowo i organizacyjnie wyjazdy misjonarzy z terenów Rzeczypospolitej na wschód. Projekty założenia placówek misyjnych podległych polskim gałęziom zakonów, odpowiednio trynitarzy na Krymie i jezuitów w Persji, które powstały w ostatnich latach panowania króla, w końcu nie doczekały się realizacji, między innymi ze względu na brak poparcia dla nich przez Rzeczpospolitą w późniejszym okresie.

\section{BIBLIOGRAFIA}

\section{Źródła rękopiśmienne}

AGAD, Archiwum Publiczne Potockich, 47, t. 1, fol. 268-270.

Archivio Storico di Propaganda Fide w Rzymie.

Rossiiskaia Natsional'naia Biblioteka w Petersburgu, Otdel Rukopisev, Fond 917, krymskie księgi sądowe nr 22, 23a i b, 25.

Scritture referite nei Congressi, t. 1, Georgia, fol. 329 r-v, 485.

Scritture originali referite nelle Congregatione, t. 527, fol. $320 \mathrm{r}-\mathrm{v}, 321 \mathrm{r}-322 \mathrm{v}$.

\section{Źródła drukowane}

A Chronicle of the Carmelites in Persia. The Safavids and the Papal Mission of the $17^{\text {th }}$ and $18^{\text {th }}$ Centuries, vol. 1, ed. H. Chick, London 2012 [reprint].

Abdulgaffar Kyrymi, Umdet al-akhbar, trans. D.D. Pashaoglu, Kazan 2014.

Der Tarih-i Mehemmed Giray - Eine Osmanische Quelle zur Belagerung Wiens durch die Türken im Jahre 1683, red. i tłum. M. Köhbach, ,Zeszyty Naukowe Uniwersytetu Jagiellońskiego. Prace Historyczne" 1983, R. 75, s. 137-164.

Essebüsseyyar ili sem 'planet soderžavščii istoriu krymskix xanow ot Mengli Girej Xana pierwogo do Mengli Girej Xana vtorogo t. e. s 871/1466 po 1150/1737, stos. Mirza Kazembeg, Kazan 1832. 
Jan Sobieski, Listy do Marysieńki, oprac. L. Kukulski, Warszawa 1962.

Kara Mustafa pod Wiedniem, red. i tłum. Z. Abrahamowicz, Kraków 1973.

Księga podróży Ewliji Czelebiego (Wybór), red. Z. Abrahamowicz, thum. Z. Abrahamowicz, A. Dubiński, S. Płaskowicka-Rymkiewicz, Warszawa 1969.

Pisma do wieku i spraw Jana Sobieskiego, t. 1, cz. 1-2, wyd. F. Kluczycki, Kraków 1880.

Schulhoff I., Megilat Oven, red. i tłum. P. Agostino, Roma 1982.

The Ottoman Survey Register of Podolia (ca. 1681). Defter-i Mufassal-i Eyalet-i Kamaniçe, vol. 1, ed. D. Kołodziejczyk, Cambridge, MA 2004.

Źródła do poselstwa Jana Gnińskiego wojewody chełmińskiego do Turcyi w latach 1677 1678, wyd. F. Pułaski, Warszawa 1907.

\section{Opracowania}

Abrahamowicz Z., Tło polityczne i ekonomiczne wyprawy wiedeńskiej Kary Mustafy, „Kwartalnik Historyczny” 1983, R. 90, s. 21-54.

Bednarz M., Ignacy Franciszek Zapolski SI. Dyplomata i misjonarz w Persji pod koniec XVII w. [w:] F.A. Plattner, Gdy Europa szukała Azji, tłum. M. Bednarz, A. Starzeński, Kraków 1975, s. 371-386.

Brzeziński S., Misjonarze i dyplomaci polscy w Persji w XVII i XVIII wieku, Potulice 1935. Chowaniec C., Sobieski wobec Tatarszczyzny 1683-1685, „Kwartalnik Historyczny” 1928, R. 42, s. 59-66.

Chowaniec C., Z dziejów polityki Jana III na Bliskim Wschodzie 1683-1686, „Kwartalnik Historyczny" 1926, R. 40, s. 151-160.

Clarke C., Iron Kingdom: The Rise and Downfall of Prussia, 1600-1947, Cambridge 2006. Encyklopedia wiedzy o jezuitach na ziemiach Polski i Litwy 1564-1995, oprac. SJ L. Grzebień, Kraków 1996.

Gemici N., Evliya Çelebi’ye Göre II. Viyana Muhasarasında Kırım Hanı'nın Yanlış Tutumu Sebepleri [Powody niewłaściwego zachowania chana krymskiego podczas drugiego oblężenia Wiednia według Ewliji Czelebiego], „Türkiyat Mecmuası” 2016, C. 26, S. 1, s. 131-146.

Inglot M., Misjonarze jezuiccy na Krymie od początku XVII do połowy XVIII wieku [w:] Polacy na Krymie, wyd. E. Walew and er, Lublin 2004, s. 177-204.

Jarzmo Ligi Świętej? Jan III Sobieski i Rzeczpospolita w latach 1684-1696, red. D. Milewski, Warszawa 2017.

Kamieński A., Polska a Brandenburgia-Prusy w drugiej połowie XVII wieku. Dzieje polityczne, Poznań 2002.

Kellner-Heinkele B., Who Was 'Abdulghaffar el-Qirimi? Some Notes on an 18th Century Crimean Tatar Historian, „Journal of Asian History” 1998, vol. 32, no. 2, s. 145-156.

Koczegarow K., Rzeczpospolita a Rosja 1680-1686. Zawarcie traktatu o pokoju wieczystym, red. T. Szwaciński, Warszawa 2017.

Kołodziejczyk D., Das Krimkhanat Als Gleichgewichtsfaktor in Osteuropa (17.-18. Jahrhundert) [w:] The Crimean Khanate Between East and West (15th-18th Century), Hrsg. D. Klein, Wiesbaden 2012, s. 47-58.

Kołodziejczyk D., Ottoman-Polish Diplomatic Relations (15 th $-18^{\text {th }}$ Century). An Annotated Editions of 'Ahdnames and Other Documents, Leiden-Boston 2000. 
Kołodziejczyk D., The Crimean Khanate and Poland-Lithuania. International Diplomacy on the European Periphery $\left(15^{\text {th }}-18^{\text {th }}\right.$ Century). A Study on Peace Treaties Followed by Annotated Documents, Leiden-Boston 2011.

Kołodziejczyk D., Tibet in the Crimea? Polish Embassy to the Kalmyks of 1653 and a Project of an Anti-Muslim Alliance, „Acta Poloniae Historica” 2016, R. 114, s. 231-253.

Kołodziejczyk D., Jaśkowski S., Mnatsakanyan P., Stosunki dawnej Rzeczypospolitej $z$ Persja Safawidów w świetle dokumentów archiwalnych, Warszawa 2017.

Król Jan III Sobieski i Rzeczpospolita w latach 1674-1683, red. D. Milewski, Warszawa 2016.

Królikowska N., Polish-Lithuanian Missionaries in the Crimea and in the Northern Caucasus in the 17th Century [w:] Türkiye-Polonya Ilişkilerinde "Temas Alanlarl" (1414-2014) Uluslararası Konferansı Bildiler Kitabı, haz. N. Królikowska, H. Topaktaş, Ankara 2017, s. 403-413.

Krzyszkowski J., Entre Varsovie et Ispahan. Le P. Ignace-François Zapolski S.I., „Archivum Historicum Societatis Jesu” 1949, R. 18, s. 85-117.

Madej Z., Z dziejów misji polskiej na Krymie, „Sacrum Poloniae Millenium”1958, R. 5, s. 521-538.

Matthee R., Persia in Crisis. Safavid Decline and the Fall of Isfahan, London-New York 2012, s. 130-137.

Matthee R., Poverty and Perseverance: The Jesuit Mission of Isfahan and Shamakhi in Late Safavid Iran, „Al-Qantara” 2015, vol. 36, s. 463-501.

Miazek-Męczyńska M., Indipetae Polonae - kołatanie do drzwi misji chińskiej, Poznań 2015.

Natoński B., Poplatek J., Jan Gostkowski [w:] Polski stownik biograficzny, t. XLVI, s. 359-360.

Počekaev R., Kırım Hanı Murat Giray'ın Adlı Reformu [Reformy prawne chana Murada Gireja], „Belleten” 2011, C. 75, s. 571-578.

Seyyityahya N., Proishoždenie Seiida Muhammeda Rizy (k voprosu o meste ego "Semi planet» sredi proizvedenii krymskoi istoričeskoi prozy XVIII veka), „Kultura Narodov Prichernomora" 2003, C. 44, s. 35-41.

Seyyityahya N., Učebnyi iz Karasu Abdul'gaffar Kyrymi i ego istoričeskoe cočinienie [w:] Čoban-zade. Sbornik materialov I krymskoi mežnunarodnoi konferencii. Belogorsk (Karasubazar), 23-25 maja 2012 g., sost. A.R. Emirov, Symferopol 2013, s. 222-242.

Stopka K., Syri (Siri, Siriensis, Siricki de Syri) Zgórski (Zgorski, Zgurski) Salomon [w:] Polski stownik biograficzny, t. XLVI, s. 285-288.

Vermote F., Passage Denied! Dangers and Limitations of Jesuit Travel Throughout Eurasia During the Seventeenth and Eighteenth Centuries, http://worldhistoryconnected.press.illinois.edu/10.3/forum_vermote.html (dostęp: 30.05.2018).

Wasilewski W., Wyprawa bukowińska Stanisława Jabłonowskiego w 1685 roku, Warszawa 2002.

Woliński J., Pośrednictwo tatarskie w wojnie polsko-tureckiej 1674-1675, „Polityka Narodów" 1934, R. 4, s. 11-33.

Woliński J., Sprawa pruska 1673-1675 i traktat jaworowski [w:] idem, Z dziejów wojny i polityki w dobie Jana Sobieskiego, Warszawa 1960, s. 16-56.

Wójcik Z., Jan Sobieski, Warszawa 1983.

Wójcik Z., Mediacja tatarska między Polska a Turcją w roku 1672, „Przegląd Historyczny” 1962, R. 53, nr 1, s. 132-150. 
Wójcik Z., Some Problems of Polish-Tatar Relations in the Seventeenth Century. The Financial Aspects of the Polish-Tatar Alliance in the Years 1654-1666, „Acta Poloniae Historica" 1966, R. 13, s. 87-102.

Zaicev I., Krymskaia istoriografičeskaia tradicia XV-XIX vekov, Moskva 2009. 